\title{
Challenges for the Transport and Logistics Services Business: The Case of Lithuania
}

\author{
Neringa Langviniené ${ }^{1}$, Gelminè Sližiene் ${ }^{2},{ }^{1,2}$ Kaunas University of Technology
}

\begin{abstract}
The study reveals the challenges met by Lithuanian enterprises of transport and logistics services business when they are face-to-face with growing economy and high competition in the European Union services market. It identifies the problems arising, as well as possibilities to compete and to win in the market. Lithuania is taking its leadings positions in the transport and logistics services industry by the share of transport and logistics, employment rate and share of the export of services in GDP. Due to the significant role of impact of these services on the Lithuanian economy challenges for the transport and logistics services business enterprises prevail.

The research methodology is based on the comparative analysis of data on transport and logistics services industry of Lithuania and on the average of European Union. Challenges for the future of Lithuanian transport and logistics services business are defined and managerial implications in order to sustain its leading position in the export of these services are shaped.
\end{abstract}

Keywords - International trade in services, Lithuanian economy, services export, transport and logistics services industry.

\section{INTRODUCTION}

Due to the success in the services business, many of Central and Eastern European countries became the competitors of the equal value for the earlier members of European Union. According to the reports of Lithuanian banks in 2013 and 2014, the services that were earlier underestimated as an important sector of the international trade economy - now trade even faster than the trade of merchandise already for several decades [1], [2]. The international trade in services from the emerging countries in Europe, as well as in such emerging countries as India, China and Russia demonstrated large impact on the economies of these countries.

As Kandilov and Grennes state, many of Eastern and Central European countries become important exporters of many types of services to the entire European Union market [12]. Even if Grönroos, Edvardsson et al., as well as Hiziroglu underline the features of services which usually limit the possibility to export [8], [6], [9] such as poor possibilities to trade them abroad, perishability, heterogeneity, and one of the most important - incapability to separate the customer and services supplier in the services producing and consuming process - the results of the research by Kandilov and Grennes demonstrate that the services export could overcome geographical distances between consumers and providers, countries, etc. [12]. Despite of services being intangible, nonstorable, Dettmer found that the geographical distance is less important for the export of the commercial services than for others [5].
Of course, a few of obstacles for selling services internationally still exist: services usually require the participation of the consumer, of the supplier, and both of them. That is why Langvinienè and Lipsey state many reasons, which do not allow the services to reach the level of merchandise trade [14], [16].

As International Trade Statistics of the World Trade Organization shows, the international trade in several services still has many opportunities to be competitive and even to overcome the volume of international trade in merchandize [11]. Here the clear share of the services export among the countries in the European market, as well as in the global, could be visible.

According to the statistics of the World Trade Organization, while, for example, Czech Republic and Hungary are successful leaders in the export of tourism and travel services, they are also known in the export of audit and accountant services, India - in the export of information and communication technologies, Thailand in the wellness and health tourism, Luxembourg - in the financial and insurance [10], [11]. However, many countries are taking their leading positions in several services only; it means they are specialized enough.

International trade in services plays an important role in the development of the entire Lithuanian economy, as well as in services economy.

Paul, Reinsdorf and Slaughter state that the export of the transport and logistics services from Lithuania has already reached the level of the economy of the period before the global financial crisis [19], [21] and is demonstrating very positive trends further. The volumes of freight transport services by road, sea, air and railway exceeded their volumes before 2008s. The data of statistics show that the salaries of employees engaged in the Lithuanian transport and logistics services industry already overrun the height of salaries in 2007 - 2008 [24].

Gross domestic product (GDP) in Lithuania from the transport and logistics services industry plays an important role. That is why the policy in the transport and logistics services industry is very sensitive in Lithuania. According to the Statistics of Lithuania, $7 \%$ of Lithuanian citizens work in the transport and logistics services industry and create $13 \%$ of total GDP [13]. Rojaka found that while comparing to the average of European Union (28 members), the total employment in this sector is $5 \%$ and creates quite similar share of GDP, it is $4.9 \%$ [22]. The efficiency of the Lithuanian transport and logistics services industry is actually twice higher than the average of 28 members of EU. 
The actuality of the research is related to the dominating role of the transport and logistics services sector for the Lithuanian economy, Lithuanian export and especially services export and meeting the challenges of the enlarged European market.

Challenges for the transport and logistics services enterprises are understood as problems arising in business development, which should be identified and overcome in future, as well as opportunities for expanding the business attempting to win in the competitive services environment. In the common terms, the challenge is understood as a call to participate in the competitive situation in terms of ability or strength, as a call to prove the competitive advantage over others. The transport and logistics services industry is one of the most competitive one, which has big influence of many actors in the transport and logistics services industry, which is not limited by borders of the country. Lithuanian transport and logistics services providers satisfy the needs and demand of different users of transport in the entire EU market and CIS countries; transport means cross the border without any limitations (except the quality, pollution requirements for transport means); drivers could be employed from any country - EU or CIS, etc. The transport and logistics services sector itself is international.

The urgency of Lithuanian transport and logistics services business strategy is underlined by instability of Russian politics and economy which is getting slow after the turbulence in Ukraine. Due to the restrictions in Russian territory for TIR, the economics suffers large losses. These restrictions worsen the business relationships and economic environment. The majority of Lithuanian transport and logistics services turnover is related to the demand of services in the Russian market, and unfavourable situation between Russia and Ukraine and the European Union countries forces the politicians of Lithuania, as well as executives to think about the plan " $\mathrm{B}$ " if the situation in these services export will get even worse.

Langvinienè and Sekliuckienè state that as Lithuanian transport and logistics services export has the dominating role [15] in the whole export of the economy, it is very important to foresee and overcome obstacles to maintain the leading position in this services market. Sekliuckienè and Langvinienè on the basis of the international trade statistics of European Union countries underline that $60 \%$ of all services export from Lithuania is created on the grounds of the transport and logistics services industry [23]. The EU-28 average is $22 \%$ only; that means that importance of these services for this country is unnegotiable.

The research questions in the article can be formulated as follows: What challenges of Lithuanian transport and logistics services business meet in order to maintain the leading position in the export of the European Union market? What changes could be obvious in the share of services export from Lithuania, as compared to other EU members? What actions and strategy should be prepared to keep the positive trend in leading the transport and logistics services market in order to exploit the position in the competitive international services market?

The aim of the article is to disclose the main challenges in Lithuanian transport and logistics services business enterprises in the growing competition market.

The following tasks for the research were formulated:

1) To identify the main changes in the Lithuanian transport and logistics services industry for entering the international arena;

2) To evaluate the position of Lithuanian transport and logistics services business considering the entire services economy of the country;

3) To identify the challenges/opportunities for Lithuanian transport and logistics services providers to compete in the EU and in Central and Eastern European market, or even both of them.

Managerial implications of the research are the underlined challenges for the Lithuanian transport and logistics services business, exploiting the abilities in the open European Union market in order to shape the main streamlines for business development.

The methodology of the article is related to the analysis of the scientific literature, comparative analysis of the statistical and other secondary data of the transport and logistics services industry in Lithuania and entire EU-28 market.

\section{CHANGES IN THE INTERNATIONAL TRANSPORT AND LOGISTICS SERVICES TRADE}

Broussolle states that the cross-border trade in services is still scarce [4] even if modern technologies, activities in liberalization, Services Directive, etc., are implemented in order to extend the trade and to easier cope with services features in many cases.

Such scientists as Reinsdorf and Slaughter as well as. Langviniene agree that the international trade in services probably will never reach the volume of international trade in merchandize [21], [14], but explosive rise of their export undoubtedly forces to look with more attention to opportunities as well as challenges to meet the requirements of high competition in the international services market.

Forecasting the changes in the international services market Langviniene identified that the following point should be considered: more than half of all foreign direct investment is made in the services industry [14]. The turnover of foreign services subsidiaries recently has grown 3.5 times faster than the export of goods and services totally. Two incentives for the growth of the influence of international trade in services could be defined.

○ Direct incentive, as domestic services trade, as well as employment is dominating in the majority of the developed and emerging economies and exceeds the agriculture and production economies altogether.

o Indirect incentive:

a) as international trade of goods, other services, such as architectural, cultural, travel, etc. - shapes the demand for the transportation and logistics as well; 
b) the countries, which are able to export transport and logistics and have competitive advantages in this services market, usually gain the possibility to compete in other services or merchandize market (for example, delivering products to any country or to any destination).

The Lithuanian economy is facing the challenges that arise after the global financial crisis and should be able to take many strategic decisions in all business, as well as in services economy.

The year 2009 was negative because of the quick drop in the export of total services (Fig. 1), merchandize and total amount of them. The data of the statistics show the growth in export starting from 2009, and annual growth has been positive until now.

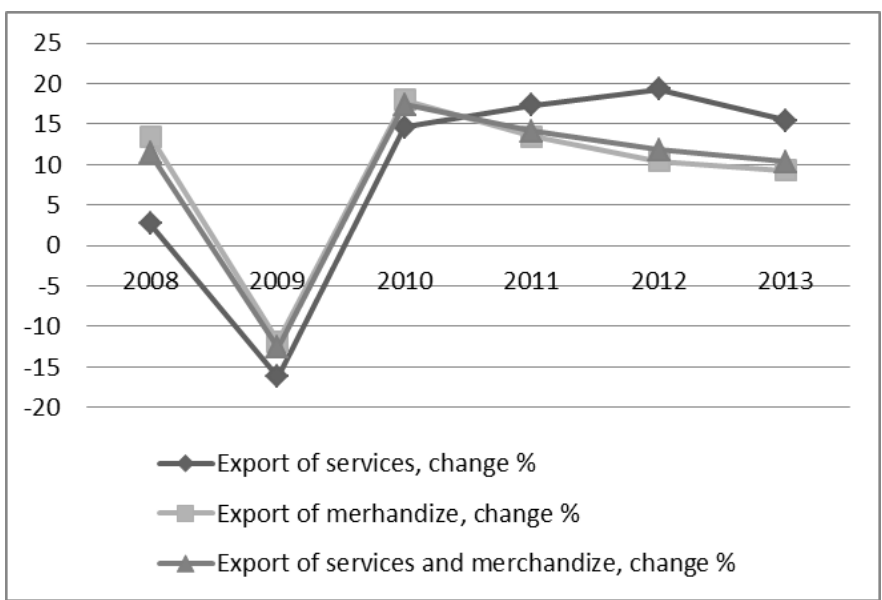

Fig. 1. The growth of the services export from Lithuania compared to the export of merchandize in 2008-2013, percent.

As seen from the statistical data in Lithuanian DNB report on export, the Lithuanian export of services is growing much faster than merchandize after the drop in 2009 [2]. As Railienè and Sližiené found, transport and logistics services sector is the sector, which reacts strongly to each economic fluctuation through the influence on the turnover of the services enterprises, as well as on the amount of the activities and services and the number of participators of these services business [20]. Consequently, due to the economic changes of the entire economy, the changes in the transport and logistics services sector could be obtained, and, conversely, if transport and logistics services suffer from the changes in demand, stricter requirements, and so on - the economy of the country usually suffers.

According to the International Trade and Market Access Data, in comparison with other European Union countries, the Lithuanian export of services grows fast enough [10], which confirms more favourable situation for the recovery of economy.

As we can see from Fig. 2, both the drop and the growth of the Lithuanian services sector, compared with the average of European Union countries, was the largest one. The drop in 2009 , compared to the year before, was $-23 \%$ (average of the European Union was $-9 \%$ ) and the growth in 2011 of the services export from Lithuania was $+28 \%$, while the average of the European Union was $+13 \%$. That allows us to assume that Lithuanian services business is more sensitive to economic turbulences than the average of the European Union.

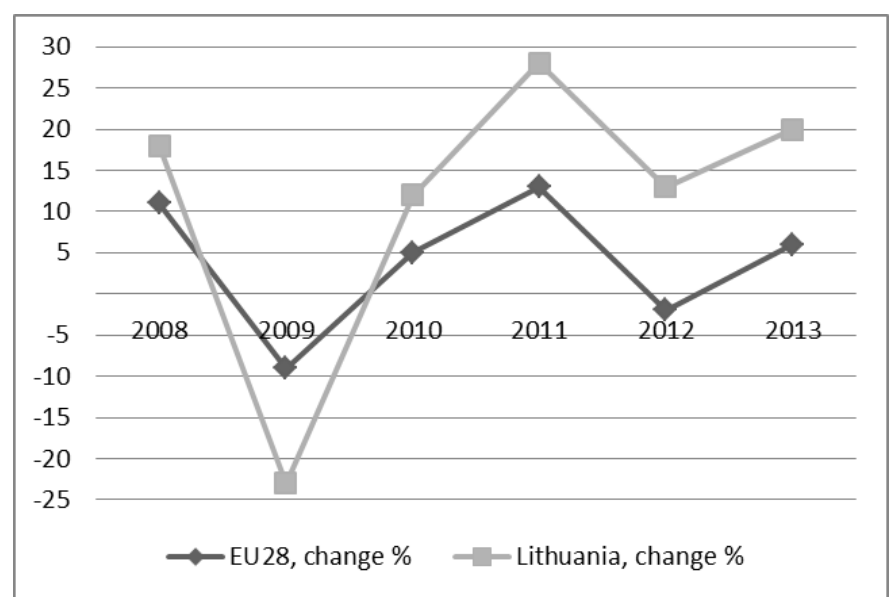

Fig. 2. The growth of the services export from Lithuania compared to the export from EU in 2008-2013, percent.

It should be noticed that the growth of export from Lithuania was visible in $2012(+13 \%)$, too, while the same year the export from the EU member states was negative ( $-2 \%$ compared to the year before).

It should be noted that the services were included into the international services trade statistics.

According to the World Trade Organization, international services could be attributed to one of the following sectors [11]:

1) transport and logistics;

2) travel and tourism;

3) governmental services;

4) other business services.

International Trade Classification in services provides more detailed classification of the international services, too. For example, transport and logistics services could be attributed to the road, air, railway, sea, pumps transportation, transportation of passengers, loads, etc. Travel and tourism could be divided into leisure and business travel, and so on.

The transport and logistics services, as well as travel and tourism services create approximately over one quarter of the export of international services. The largest sector of other business services, which includes operational leasing and miscellaneous business, professional and technical services such as legal, accounting, management consulting, public relations, creates more than one quarter of other international services volume. Computers and information technologies services, communication, construction, financial and insurance services, personal, recreational and cultural services, royalties and license fees - constitutes 1 to $8 \%$ of the total international services trade share.

The Statistics of International Trade on services confirm the growth of total volume of the transport and logistics services industry [11]. The transport and logistics services sector is one of the most perspective and fastest growing sectors in Lithuania. Langviniene states that it links to the scientific and technological progress, movement of the products, services and labour, transformation of the enterprises: merging, 
acquisitions, changing the field of activity, and structural and environmental changes [14].

Lipsey found that knowledge share acts as main influencer in the development of international trade in services [16]. In addition, even if industrial and agricultural economies successfully absorb the knowledge of technologies, equipment, employee's capabilities, the same is significant for the services economy as well.

The growth of the export of the transport and logistics services from the EU-28 compared to the rest of world is the lowest. Data of statistics show that export of services generally from European Union of Lithuania is growing. However, the change in the transport and logistics services export in the international trade is negative one, according scientific research of M. Reinsdorf and M. J. Slaughter [21]. On the grounds of the Statistical data [21] the export share of the transport and logistics services has changed significantly compared to the rest international services trade (governmental, information and communication technologies, travel, other business services, etc.).

According to Langvinienè, Reinsdorf and Slaughter, Spiriajevas, Bjelić, Van der Marel, Grigorovici, Love and Lattimore there are some reasons why the demand for international transport and logistics services may have reduced:

- Bigger amount of containers for the transport and logistics is used [14];

o The processes of the logistics are better optimized [14];

o The developed domestic transport systems minimize the dependence on foreign services [25];

- Many of services' statistics could be "moved" to the measurement of other services. Particularly because of that reason the costs for transport and logistics services often are included in the costs of material items [21];

o The demand for the transport and logistics services to be bought internationally could be replaced by substitutes. The labour is also moving from one country to another, that relays the demand for international trade in services [3];

o The growing regulation for international transport and logistics services trade [18], as well as higher limitations compared to requirements for other commercial services, could deteriorate the opportunity to trade the transport and logistics services internationally;

o The higher direct investments in foreign services affiliates are superior to manufactory sector as traders establish commercial presence in foreign markets, which also limits the demand for international transport and logistic services [7].

Of course, other causes for the drop in the transport and logistics services share also could be possible - the countries are developing and the structure of their export could change because of the reasons of the organic development.

The influence of the countries on the international trade in services is not equal. Developed countries and the countries of OECD (Organization for Economic Co-Operation and Development) generate the largest part of the export of services. According to the Statistics of World Trade Organization the import of the transport and logistics services is much higher than export as essentially the developed countries import more [10], [11].

Presently the export of the transport and logistics services is shaped due to developing and emerging countries, which have competitive labour (for example, drivers for long distances, multilingual managers), know-how (experience in Western and European countries) and relatively good infrastructure.

Lithuanian export dominance in the transport and logistics services, on the one hand, defines the country as a representative country of the developing emerging market, which does not specialize usually in other than transport and travel services sector. On the other hand, keeping the clear strategy and specialization in the transport and logistics opens many opportunities to serve the entire European Union market that is challenging enough for business enterprises in a rather small European Union country.

\section{RESEARCH METHODOLOGY}

The aim of the survey was to disclose the changes as well as challenges for Lithuanian transport and logistics services industry. The discrepancy between EU-28 average and changes in Lithuanian transport and logistics services industry was identified through the following tasks:

1) to evaluate the position of the Lithuanian transport and logistics services industry on the behalf of European Union common international trade in services (export, import);

2) to develop the index of the Lithuanian transport and logistics services international trade impact on Lithuanian economy;

3) to identify the direction of the development and streamlines of the transport and logistics services industry.

The analysis of the secondary data is implemented based on the statistics of World Trade Organization, Lithuanian Departments of Statistics, public reports of financial institutions, banks, etc.

The comparative analysis of the data of Lithuania and the average of 28 European Union member states, as well as content data analysis and causative analysis is implemented.

The average of services export, the structure of services export, and the dynamics of the export of services are calculated by authors on the basis of the secondary data.

The investigation period covers 2008 - 2013. The period of the investigated data was chosen trying to get deep into the time of the boom (2008) and recession of the economy (2009-2010), as well as recovery after the global financial crisis ( end of 2010 to 2013).

Due to the lack of the data, the ratio share of economic activities in the Lithuania and European Union GDP structure and changes cover 2012 instead of 2013. Analysing the Lithuanian transport and logistics services destination by countries we have supplied data since 2009.

Limitations of the findings of the analysis are related to the possible bias on calculations made on EU-28 members. One of EU member, it is Croatia joined the Union in the middle of 2013. That is why some of the data could be the cause of 
inaccuracy of uneven statistical data of earlier members and new member of EU.

Transport and logistics services industry in European Union market depends on the prices of the resources, such as price for diesel, wages for drivers, which are very similar in majority of EU countries. The technical requirements for the transport park of transport and logistics services suppliers are unified for all members of the market of EU. After joining the EU Lithuanian services suppliers had accepted and followed them, so recent changes in requirements are equal for all providers of EU services market. Authors of the article accept the precondition that the increase of the price for petroleum and of wages in the competing markets is very similar. Thus, these aspects in the research are not included.

\section{FINDINGS OF THE RESEARCH}

The Report of the Lithuanian Bank illustrated that the growth of the Lithuanian transport and logistics services impacted the increasing growth of the share in European Union GDP structure [1]. The share of transport and logistics services of Lithuania in the European Union GDP changed to positive (Fig. 3).

While education services $(-10 \%)$, public administration and social security $(-10 \%)$, information and communication technologies $(-12 \%)$, real estate services $(-17 \%)$, health care and social services $(-20 \%)$, financial and insurance services $(-43 \%)$ of Lithuania decreased their share in the European Union GDP, the transport and logistics in Lithuanian GDP increased from 1.9 in 2008 to 2.8 in 2012, it is by $47 \%$.

Except for the share of the Lithuanian transport and logistics services in GDP in the EU GDP, only the share of water supply, sewage, waste management (+25\%), manufacturing $(+18 \%)$, agriculture $(+9 \%)$ and domestic trade $(+6 \%)$ had increased.

Comparing the services export structure from Lithuania and other member states of European Union, Lithuania was competing for the leader's position in the transport and logistics services with another European Union country Denmark (see Fig. 4).

As we can see, Lithuania is one of the strongest leaders in the export of transport and logistics services of the European Union. More than $60 \%$ of total services export consists of transport and logistics. It should be noted also that Denmark does not give up the position in these services market, as the export from this country is grounded on the transport and logistics services, too $(62 \%)$.

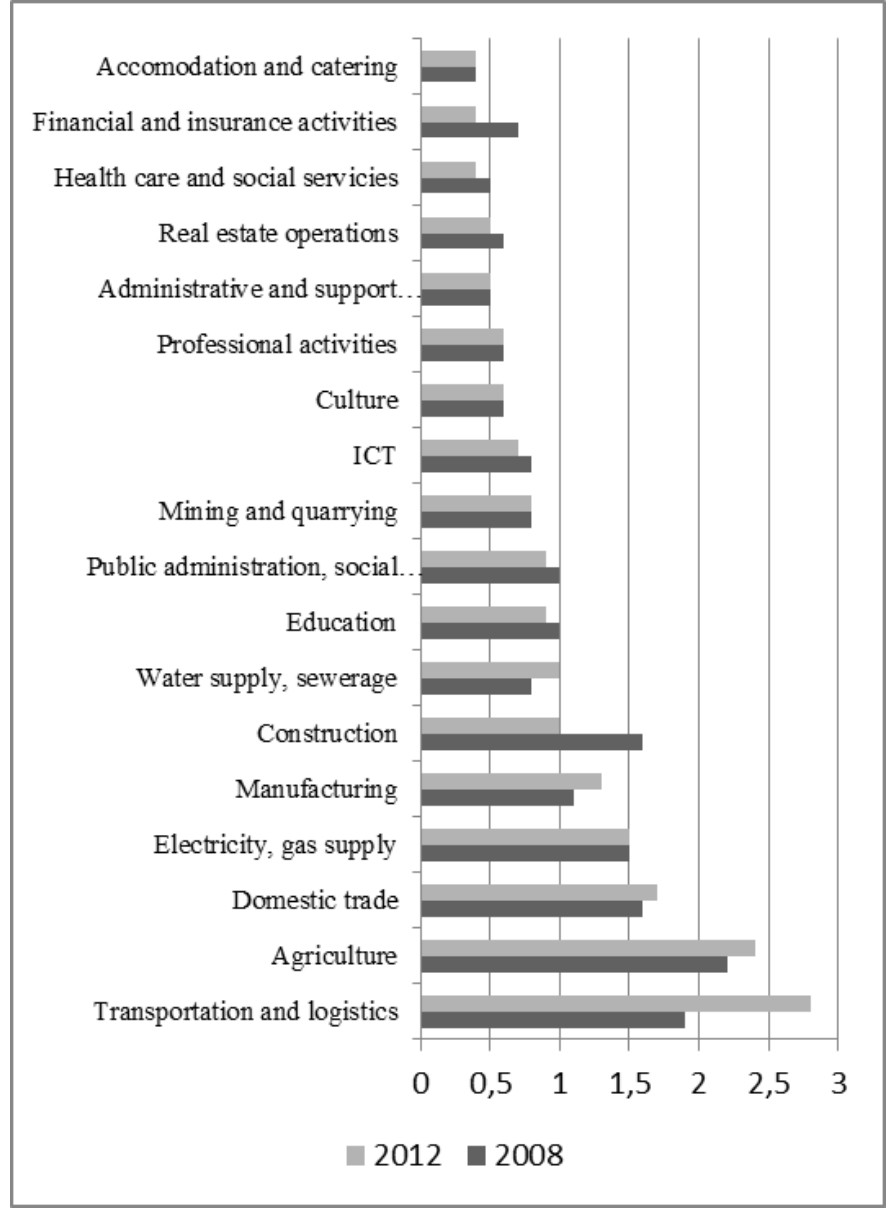

Fig. 3. The change in the share of the economic activities in the Lithuanian and EU GDP structure in 2008-2012.

According to the Lithuanian Exporters Database, making comparing estimations, the export of transport and logistics services from the average of EU-28 is $22 \%$ only, which means more than twice less than from Lithuania [29]. The Latvian and Greece transport and logistics services export is significant enough, too ( $51 \%$ of all services export).

The situation of the import of services is quite similar to the export of services (Fig. 5).

The Lithuanian import of transport and logistics services is definitely leading: $59 \%$ of the imported services are those of the transport and logistics. The other two EU members-leaders are Denmark and Greece (54\% and $53 \%$ respectively). The import of transport and logistics services to EU-28 makes $24 \%$ only. 


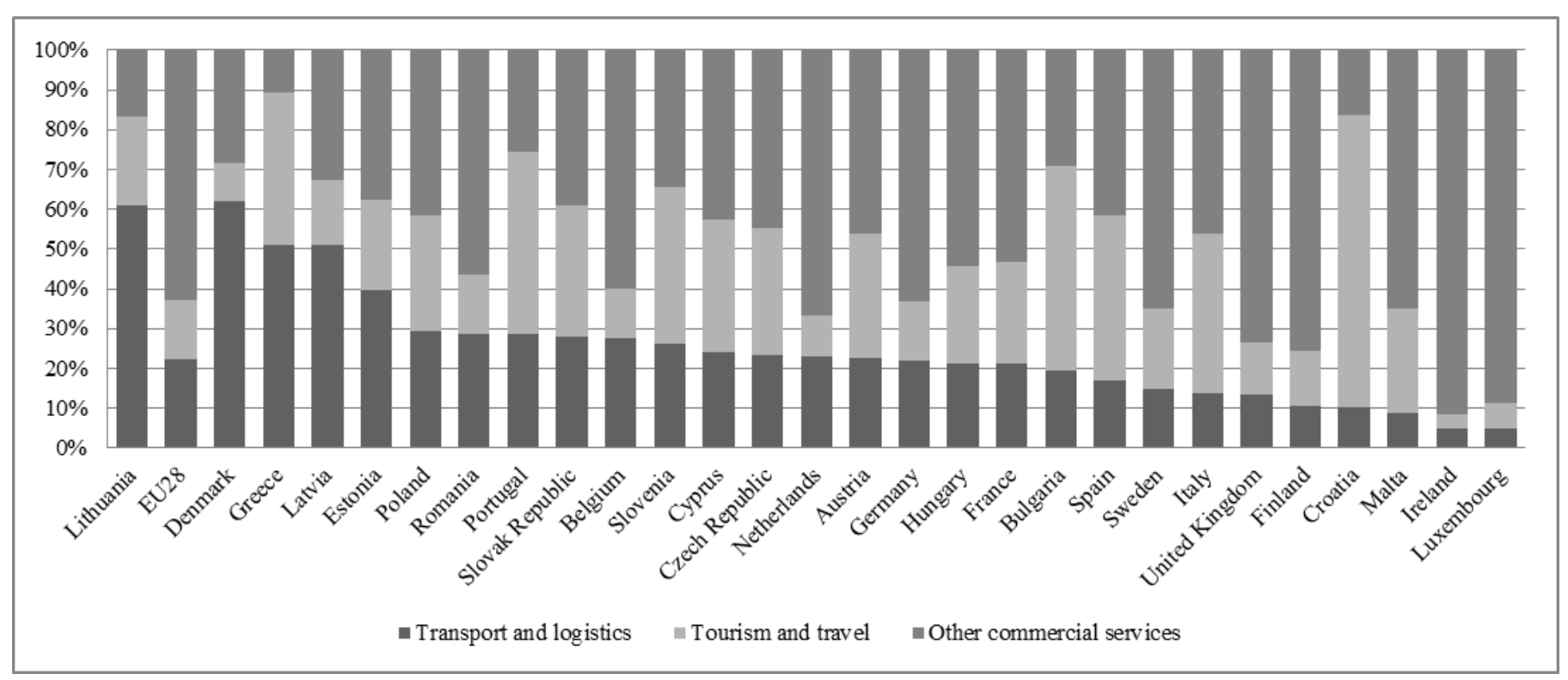

Fig. 4. The Lithuanian services export structure compared to the structure of other EU member countries, as well as the average of EU-28 in 2013 , percent.

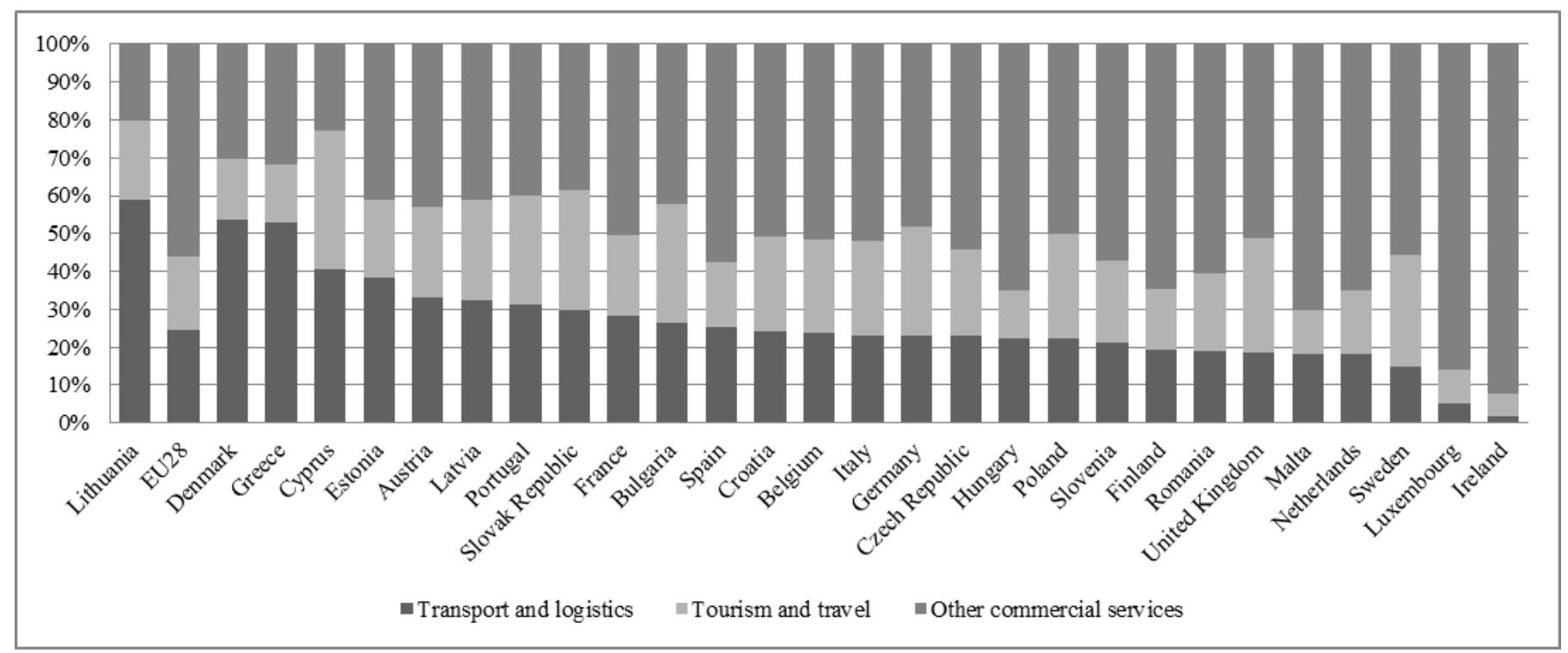

Fig. 5. The Lithuanian services import structure compared to the structure of other EU member countries, as well as the average of EU-28 in 2013 , percent.

Getting more deep into the changes in the turnover of the Lithuanian transport and logistics services international trade, according to the World Trade Organization, and compared to the changes in the turnover of the EU international trade, it should be noted that the international trade in services starting from 2009 (the major point of recession in the transport and logistics) was growing (see Table I) [11].

The year 2009 was the worst for transport and logistics services industry for Lithuania, as well as for other EU-28 members: the drop of international trade in services respectively was $27 \%$ (Lithuania) and $12 \%$ (EU-28). It should be noted also that the export of transport and logistics services from Lithuania was growing much faster than from the average of EU-28.
TABLE I

THE CHANGE IN THE INTERNATIONAL TRANSPORT AND LOGISTICS SERVICES TRADE FROM LITHUANIA AS WELL AS EU-28 IN 2008-2013

\begin{tabular}{|l|l|l|l|l|l|l|}
\hline Index/Year & $\mathbf{2 0 0 8}$ & $\mathbf{2 0 0 9}$ & $\mathbf{2 0 1 0}$ & $\mathbf{2 0 1 1}$ & $\mathbf{2 0 1 2}$ & $\mathbf{2 0 1 3}$ \\
\hline $\begin{array}{l}\text { Lithuanian } \\
\text { export, } \\
\text { million \$ }\end{array}$ & 2875 & 2088 & 2420 & 3089 & 3551 & 4319 \\
\hline Change, \% & +23 & -27 & +16 & +28 & +15 & +22 \\
\hline $\begin{array}{l}\text { EU28 } \\
\text { export, } \\
\text { million \$ }\end{array}$ & 409114 & 321093 & 351867 & 386112 & 373470 & 385857 \\
\hline Change, \% & +15 & -12 & +10 & +10 & -3 & +3 \\
\hline
\end{tabular}


The total growth of the transport and logistics services export from Lithuania in 2013 exceeded the level of 2008 by $50 \%$; while export from EU-28 did not reach the level of 2008. That confirms that Lithuanian share in the entire EU-28 transport and logistics services market is still growing.

The countries of the Lithuanian transport and logistics services destination during the investigated period remain to be stable (Fig. 6).

According to the Statistics of Lithuania (2013) and Lithuanian Exporters Database (2014), a few of destination countries even started to play the more important role in the Lithuanian transport and logistics services business than at the beginning of the analysed period [26], [27]. Lithuanian Exporters Database demonstrates that the transport and logistics services export share to the Russian market at the end of 2013 was already more than $28 \%$, to German market $12 \%$, to Belorussia more than $6 \%$ and to Latvia - more than $4 \%$ [28]. The number of other destination countries has been growing since 2009 and has reached the level of actually $49 \%$. One of the most important among them was Denmark and the Netherlands.

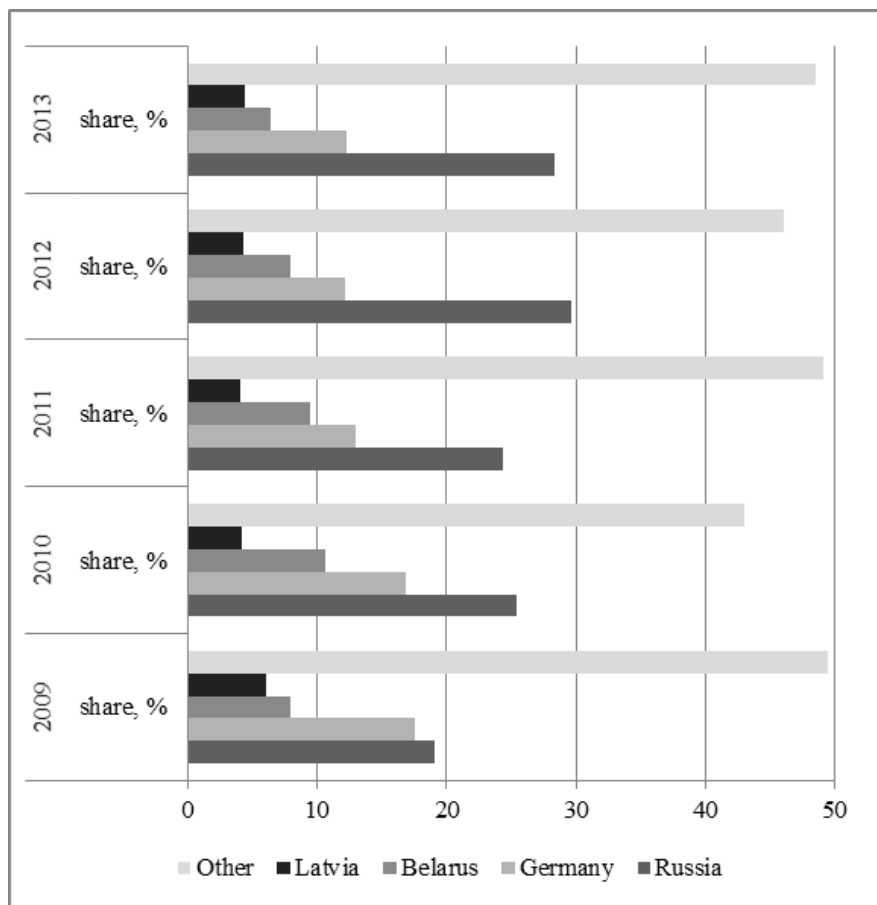

Fig. 6. The change in the share of Lithuanian transport and logistics services destination in 2009-2013.

Eastern European countries served for the Lithuanian transport and logistics services business as one of the most important drives for recovering the services export in the aftercrisis period. The selling of Lithuanian exporters in Russian market in 2008 - 2013 grew twice as fast as the total export. It is nevertheless true that the signs of less attractive market for Lithuanian transport and logistics services, as well as for other services or products, in Russia in 2013 have emerged. The geopolitics of Russia has also been unfavourable since the end of 2013. Not long ago Russian politician started to talk about the economy crisis that affected the Russian business. Serious problems for the economy are visible in other CIS countries, too; and that obviously will influence the slowing partnership between Lithuanian and Eastern markets.

\section{CONCLUSION AND MANAGERIAL IMPLICATIONS}

The findings of the survey show that the Lithuanian transport and logistics services sector still has rather strong positions in the entire European Union, Central and Eastern European market. The external business environment of the Lithuanian economy of transport and logistics industry is deteriorating due to slower economic growth in Russia. Lithuanian transport and logistics services industry is tiny in relation to the Russian economy, because the export of other services and merchandize from Lithuania to Russia is minor. However, the decreasing export of the Lithuanian transport and logistics services to Russia is recovered by certain economic growth in European Union, as well as the demand for the transport and logistics services.

Despite the decreasing share of the international trade transport and logistics services compared to other commercial services, Lithuanian share in the entire European Union GDP is definitely significant. Any mistake in the strategy in the international trade policy choosing the direction of the export could be crucial. The growing price of the fuel, wages for drivers, strict requirements for technical equipment are equal for each member of the transport and logistics services enterprise in EU. Any turbulence in EU, political situation in neighbouring countries influence the Lithuanian transport and logistics services business. That is why precise decisions at the level of Lithuanian Ministry of Economy and Lithuanian Association of Transport and Logistic Business units, as well as actions of each businessman could be urgent.

Two main streamlines in the international trade of Lithuanian transport and logistics services could be developed: European Union countries and CIS, especially Russia and Belorussia. Unwarranted future for Russian economy, as well as attempts to minimize the losses because of changes, forces the Lithuanian transport and logistics services business enterprises to look for alternative export markets, which could be able to absorb part of capabilities of exporters. The Asian market could be one of them because of the emerging economy, global business trends and transport roads infrastructure to these markets.

New destination markets could be as follows: Turkey, Balkan countries, Uzbekistan, Azerbaijan, North Africa and China. Significant role will be played by East-West Transport Corridor (EWTC), which will join transport centres in Sweden, Denmark, Germany, and Lithuania with the transport systems in Belorussia, Russia and Ukraine. This will obviously serve as global competitive transport and logistics chain with Lithuania ahead of the Eastern and Western Europe. 


\section{REFERENCES}

[1] "Baltic countries economics perspectives," [Online]. Available: https://www.dnb.lt/sites/default/files/research/baltijos_saliu_ekonomikos _perspektyvos_2013_ruduo.pdf. [Accessed: January 19, 2015].

[2] "Baltic Economic Outlook, Spring 2014," [Online]. Available: https://www.dnb.lt/sites/default/files/research/baltic_economic_outlook 2014_spring_final_1.pdf. [Accessed: June 12, 2014].

[3] Bjelić, P., "New approach in international trade analysis due to international factor movements," Zbornik Radova Ekonomskog Fakulteta u Istocnom Sarajevu, vol. 7, 2013, pp. 17-29. http://dx.doi.org/10.7251/ZREFIS1307017B

[4] Broussolle, D., "Service, Trade in Services, and Trade of Services Industries," Journal of World Trade, Vol. 48, no. 1, 2014, pp. 31-58.

[5] Dettmer, B., "International Service Transactions: Is Time a Trade Barrier in a Connected World?" International Economic Journal, vol. 28 , no. 2, 2014, pp. 225-254 http://dx.doi.org/10.1080/10168737.2013.825305

[6] Edvardsson, B., Gustafsson, A. and Roos, A., "Service portraits in service research: a critical review," International Journal of Service Industry Management, vol. 16, no. 1, 2005, pp. 107-121. http://dx.doi.org/10.1108/09604520110393386

[7] Grigorovici, C., "Quantitative and Structural Tendencies in International Services Trade," Annals of the University of Petrosani Economics, vol. 8, no. 1, 2008, pp. 247-252.

[8] Grönroos, Ch., "The perceived service quality concept - a mistake?" Managing Service Quality, vol. 11, no. 3, 2001, pp. 150-152. http://dx.doi.org/10.1108/09604520110393386

[9] Hiziroglu, M., Hiziroglu, A. and Kokcam, A. H., "An investigation on competitiveness in services: Turkey versus European Union," Journal of Economic Studies, vol. 40, no. 6, 2013, pp. 775-793. http://dx.doi.org/10.1108/JES-10-2011-0128

[10] International Trade and Market Access Data. World Trade Organization Statistics Database (SDB). [Online]. Available: http:www.wto.org. [Accessed: June 13, 2014].

[11] "International Trade Statistics 2013," World Trade Organization Statistics Database (SDB). [Online]. Available: http://www.wto.org/ english/res_e/statis_e/its2013_e/its2013_e.pdf. [Accessed: June 12, 2014].

[12] Kandilov, I. T. and Grennes, T., "The determinants of service exports from Central and Eastern Europe," Economics of Transition, vol. 18, no. 4 , 2010, pp. 763-794. http://dx.doi.org/10.1111/j.1468-0351.2010.00392.x.

[13] "Labour Market Yearbook," Lithuanian Statistics Department, 2013.

[14] Langvinienė, N., "Tarptautinè paslaugų prekyba," Kaunas University of Technology: Technologija, 2013. http://dx.doi.org/10.5755/e01.9786090209516

[15] Langviniené, N. and Sekliuckiené, J., "Transformation of international business services industry in Lithuania," Economics and management, vol. 18 , no. 2, 2013, pp. 286-295.

[16] Lipsey, R. E., "Measuring International Trade in Services," In International Trade in Services and Intangibles in the Era of Globalization, 7-70. Eds. Reinsdorf M., Slaughter, M. J. 2009, University of Chicago Press.

[17] Love, P. and Lattimore, R., "International trade: free, fair and open?" OECD publications, 2009. http://dx.doi.org/10.1787/9789264060265-en

[18] Van der Marel, E., "Trade in Services and TFP: The Role of Regulation," World Economy, vol. 25, no. 11, 2012, pp. 1530-1558. http://dx.doi.org/10.1111/twec.12004

[19] Paul, I., "Trends in supply chain management," Logistics and Transport Forum, $8^{\text {th }}$ Annual Conference Proceedings, 2013, Vilnius.

[20] Railienè, G. and Sližiené, G., "Financial valuation of business performance: the case of Lithuanian transportation and storage sector," Changes in social and business environment: proceedings of the $5^{\text {th }}$ International Conference, 2013, pp. 126-135.

[21] Reinsdorf, M. and Slaughter, M. J. (Eds), "International trade in services and intangibles in the era of globalization," National Bureau of Economic Research, 2009. http://dx.doi.org/10.7208/chicago/9780226709604.001.0001

[22] Rojaka, J., "Misija 2014: tvarus augimas vangios ekonominès aplinkos sąlygomis," Logistics and Transport Forum, $8^{\text {th }}$ Annual Conference Proceedings, 2013, Vilnius.

[23] Sekliuckienė, J. and Langviniené, N., "The challenges and opportunities for the Lithuanian international trade in services: a case of emerging market," $6^{\text {th }}$ International Conference on Services Management: conference proceedings, 2013, Oxford: Oxford Brookes University, pp. 1002-1013.

[24] "Services Profiles Statistics," World Trade Organization Statistics Database (SDB), [Online]. Available: http://stat.wto.org. [Accessed: June 12, 2014].

[25] Spiriajevas, E., "Geography of transport and international trade between the Baltic countries and Turkey," Region Formation \& Development Studies, vol. 1, no. 11, 2014, pp. 207-220.

[26] "Transport and Communications," Lithuanian Statistics Department, 2013.

[27] "Transport and Logistics 2011," Lithuanian Exporters Database [Online]. Available: http://www.enterpriselithuania.com/en/sectors/ transport-logistics. [Accessed: June 11, 2014]

[28] "Transporto paslaugų eksportas pagal šalis 2009," Lithuanina Exporters Database [Online]. Available: http://www.verslilietuva.lt/uploads/old/files/ files/PDF/paslaugu_eksportas_2009(1).pdf. [Accessed: June 11, 2014].

[29] "Transporto paslaugų eksporto tendencijos Lietuvoje 2013," Lithuanian Exporters Database [Online]. Available: http://www.verslilietuva.lt/uploads/ file/2014\%2006\%2005_VL_paslaugu_eksporto_apzvalga_2013_m\%20_fi nal.pdf. [Accessed: June 13, 2014].

Neringa Langvinienè received the Doctoral degree in Social Sciences (Business and Management) from Kaunas University of Technology in 2001.

She is currently a Professor with the Department of Strategic Management, School of Economics and Business, Kaunas University of Technology. She is the author of over 50 publications, co-author of several scientific monographs, scientific studies, handbooks and teaching books. She delivered reports at the international conferences in Cyprus, Cottbus, Tallinn, Tampere, Helsinki, Stuttgart, Budapest, Parma, etc. Her research interests include services management, services competitiveness and internationalization, services quality and services business. Her special interests are research in the transport and logistics, as well as in the health and wellness tourism sector. She has a business practice in one of the largest Lithuanian transport companies for several years as commercial director.

She received the award in the field of handbooks from Lithuanian Ministry of Education in 2006.

She has been a member of RESER (European Association in Research in Services) since 2007 and an expert for Lithuanistika database since 1997.

She is also a member of Editorial Board of the scientific journal "Business

System \& Economics" published by Mykolas Romeris University, Vilnius, Lithuania.

Address: Department of Strategic Management, School of Economics and Business, Kaunas University of Technology, K. Donelaicio Str. 20-415, LT-44239 Kaunas, Lithuania.

Phone: +370 37 300126; Mob. +370 61861169 ;

E-mail: neringa.langviniene@ktu.lt

Gelminė Sližienė received the Master's degree in Engineering and Economics in 1989, and the MBA in 2000 from Kaunas University of Technology.

She is currently a Lecturer with the Department of Management, School of Economics and Business, Kaunas University of Technology.

She is the author of over 20 publications, co-author of scientific study "Services Business in Lithuania" (2009) and the author of a textbook "Logistics operation management" (2013). She has delivered reports at the international conferences in Tallinn, Cottbus, etc.

Her research interests include services management, services business and generic controlling, marketing controlling. The special interest covers researches in the transport and logistics sector. An author is a Leading Lecturer of the course of Logistics and Operations Management in the BA program, Kaunas University of Technology.

She is a member of the working group of International Society of Controlling (IVC) "Lithuania".

Address: Department of Management, School of Economics and Business, Kaunas University of Technology, K. Donelaicio Str. 20-407, LT-44239

Kaunas, Lithuania.

Phone: +370 37300592 ;

E-mail: gelmine.sliziene@ktu.lt 